\title{
Gridded climate data from 5 GCMs of the Last Glacial Maximum downscaled to 30 arc s for Europe
}

D. R. Schmatz ${ }^{1}$, J. Luterbacher ${ }^{2}$, N. E. Zimmermann ${ }^{1}$, and P. B. Pearman ${ }^{1,3,4}$

${ }^{1}$ Landscape Dynamics, Swiss Federal Institute for Forest, Snow and Landscape Research WSL, Birmensdorf, Switzerland

${ }^{2}$ Department of Geography, Climatology, Climate Dynamics and Climate Change, Justus-Liebig-University of Giessen, Giessen, Germany

${ }^{3}$ Department of Plant Biology and Ecology, Faculty of Sciences and Technology, University of the Basque Country, UPV/EHU, Ap. 644, 48940 Leioa, Bizkaia, Spain

${ }^{4}$ IKERBASQUE, Basque Foundation for Science, 48011 Bilbao, Bizkaia, Spain

Received: 13 May 2015 - Accepted: 31 May 2015 - Published: 30 June 2015

Correspondence to: D. R. Schmatz (dirk.schmatz@wsl.ch)

Published by Copernicus Publications on behalf of the European Geosciences Union.
High resolution climate data from 5 GCMs of LGM

D. R. Schmatz et al.

\section{Title Page}

Abstract Introduction

Conclusions References

Tables Figures

14

4

Back

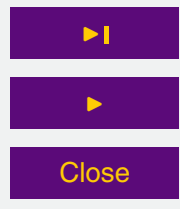

Full Screen / Esc

Printer-friendly Version

Interactive Discussion 


\section{Abstract}

Studies of the impacts of historical, current and future global change require very highresolution climate data $(\leq 1 \mathrm{~km})$ as a basis for modelled responses, meaning that data from digital climate models generally require substantial rescaling. Another shortcom-

5 ing of available datasets on past climate is that the effects of sea level rise and fall are not considered. Without such information, the study of glacial refugia or early Holocene plant and animal migration are incomplete if not impossible. Sea level at the last glacial maximum (LGM) was approximately $125 \mathrm{~m}$ lower, creating substantial additional terrestrial area for which no current baseline data exist. Here, we introduce the development

of a novel, gridded climate dataset for LGM that is both very high resolution $(1 \mathrm{~km})$ and extends to the LGM sea and land mask. We developed two methods to extend current terrestrial precipitation and temperature data to areas between the current and LGM coastlines. The absolute interpolation error is less than 1 and $0.5^{\circ} \mathrm{C}$ for 98.9 and $87.8 \%$, respectively, of all pixels within two arc degrees of the current coastline. We five global circulation models of LGM climate to a resolution of $1 \mathrm{~km}$ for Europe. As additional variables we calculate 19 "bioclimatic" variables, which are often used in climate change impact studies on biological diversity. The new LGM climate maps are well suited for analysing refugia and migration during Holocene warming following the LGM.

\section{Introduction}

Global climate models (GCMs) and regional climate models (RCMs) are essential in studying the impact of long-term climatic changes on natural and social systems (e.g. IPCC, 2014a; b and references therein). However, in their original form, these models provide climate data at a spatial scale that is much coarser than that required for climate impact studies. GCMs have resolutions of approximately 1-3 arc degrees (hundreds of
CPD

$11,2585-2613,2015$

High resolution climate data from 5 GCMs of LGM

D. R. Schmatz et al.

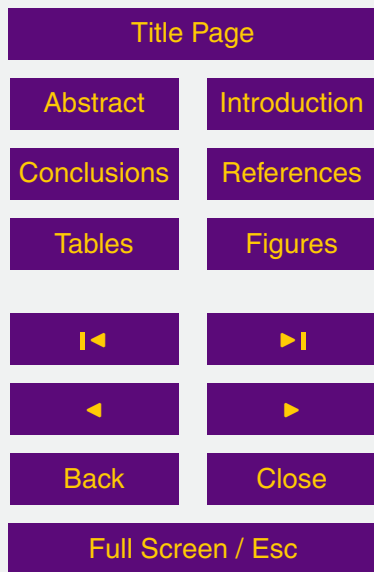

Printer-friendly Version

Interactive Discussion 
kilometres) while RCMs can be as fine as tens of kilometres. Nonetheless, climate impact studies require resolutions from $1 \mathrm{~km}$ down to $100 \mathrm{~m}$ or less (Randin et al., 2009). For example, models of the potential impact of climate change on species distributions regularly make use of such down-scaled data (e.g., Bryson et al., 2014; Maiorano 5 et al., 2013; Patsiou et al., 2014; Pearman et al., 2008). Further, impact analyses are increasingly expected to account for uncertainty that arises from specific climate models by using modelled climate data from multiple sources and constructing ensembles of results (Araujo and New, 2007; Buisson et al., 2010; Thuiller et al., 2009). To meet this need, the change factor method, also called the delta change factor method, is 10 frequently applied in the downscaling of climate data for use in studies of climate impacts, essentially producing high-resolution gridded climate data from lower resolution climate model output (Anandhi et al., 2011). This method adjusts high resolution, observed baseline climate data by adding to them interpolated climate anomalies from GCM or RCM model output. These anomalies are the differences between the modelled climate of a future scenario or a historical period, and the modelled baseline climate. Conducting change factor downscaling over continental extents can be fairly straightforward using GCM/RCM data of future scenarios (Anandhi et al., 2011). However, downscaling GCM data from simulations of historical climates using the change factor method can be problematic when discrepancies in ocean levels are substantial.

The downscaling of GCM output for historical periods, such as the last glacial maximum (LGM), provides essential data for studies in paleobiogeography (Nogues-Bravo, 2009), but use of the change factor method to construct these data encounters two substantial problems. First, observed baseline climate data, such as interpolated weather station data from Worldclim (http://www.worldclim.org; Hijmans et al., 2005), cover current land areas only. However, sea level at the LGM was approximately $125 \mathrm{~m}$ lower than it is today (Peltier, 2004). Therefore, substantial additional areas were exposed and the positions of coastlines differed clearly from their current positions, in some places by many tens or even hundreds of kilometres, as in the North Sea and Gulf of Mexico. These previously exposed areas do not currently represent terrestrial climates.

\section{CPD}

$11,2585-2613,2015$

High resolution climate data from 5 GCMs of LGM

D. R. Schmatz et al.
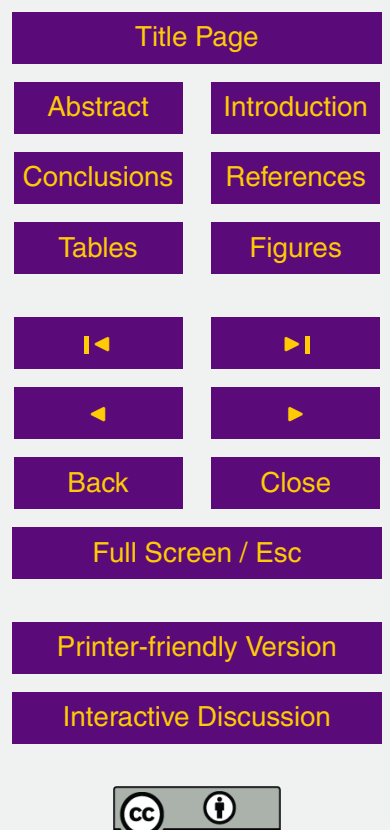
However, some form of high resolution, baseline climate data to which anomalies can be applied are required in the change factor method (Anandhi et al., 2011). One solution would be to extend the observed high-resolution baseline climate data to the ancient LGM shoreline. Here, we address the question of the potential baseline cli5 mate of low lying areas, which were exposed when the sea level was approximately equal to its level at the LGM (Peltier, 2004). We report the development and implementation of two methods for this extension, one each for temperature and precipitation data.

A second problem for the application of the change factor method in downscal10 ing data from coarse-resolution GCM simulations arises when its baseline period, used in producing the modelled climate anomalies, does not correspond to the period for which high resolution, observed climate data are available. For example, in the Paleoclimate Modeling Intercomparison Project PMIP2 (Braconnot et al., 2007) the control runs of the GCMs use boundary conditions corresponding to the preindustrial years around $1750 \mathrm{AD}$ (http://pmip2.Isce.ipsl.fr/design/boundary.shtml\#0k). There were at least 200 years between this date and the period of the weather station data used in the construction of the Worldclim global climate layers (1950-2000). During this period, global climate likely changed due to the effects of e.g. gas emissions caused by industrialization (Folland et al., 2001).

In this study, we downscale climate data from $5 \mathrm{GCM}$ simulations originating from the PMIP2 efforts for the region of Europe. One specific focus is to account for net change in surface air temperature over this 200 year gap between contemporary and preindustrial climate. We do so by using data from multiproxy-based reconstructions of monthly temperature (Luterbacher et al., 2004; Xoplaki et al., 2005) covering the past centuries. We then apply the change factor method using these newly developed base line climate data to downscale five global climate models (GCMs) from the PMIP2 database cp-3-261-2007 for the region of Europe to a resolution of 30 arc s (approx. $1 \mathrm{~km})$.

\section{CPD}

$11,2585-2613,2015$

High resolution climate data from 5 GCMs of LGM

D. R. Schmatz et al.
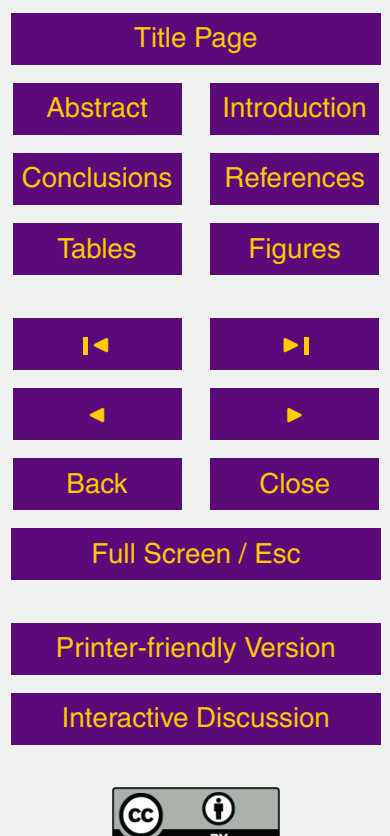
Several geographic patterns of climate are relevant to our efforts. Air Temperature depends on elevation above sea level, and the rate of temperature decrease with increasing elevation is known as the lapse rate (Rosenberg et al., 1983). This relationship is especially evident in regions of strongly varying topography, such as in mountainous 5 areas. Additionally, temperature depends on geographical position in that it decreases towards the poles due to reduced radiation. Further, the annual range of temperatures increases with the distance from the ocean (i.e. increasing continentality). Thus, temperature also depends on longitude. The influence of latitude and longitude on temperature tends to be substantial in regions where plains dominate, for example in 10 northeastern Europe. The lapse rate of precipitation is less closely linked to elevation than is that of temperature and, instead, shows high spatial and regional variability (Maraun et al., 2010). These differences led us to address temperature and precipitation baselines with different calculation methods. In our study, we present several simplifying assumptions that account for these patterns and enable the work. Further, 15 we also refer to methods that we explored but then discarded to avoid the creation of geographic artefacts and unrealistic values. The resulting methods produce baseline climate data that are useful in applying the change factor method to downscale GCM simulations to areas of continental extent larger than those at present, such as is necessary when downscaling climate models of the high glacial period. While we produced high-resolution data of LGM climates for Europe only, we present the methodology with examples from two regions, namely northwestern Central Europe with the North Sea for temperature, and the Gulf of Mexico for precipitation. These two regions are best suited to illustrate the development of the methodology.

\section{Methods}

25 We established several criteria to guide the construction of baseline climate for areas that are currently submerged. First, the current terrestrial climate of areas that are separated by geographic distance from marine coasts should remain unaltered because

\section{CPD}

11, 2585-2613, 2015

High resolution climate data from 5 GCMs of LGM

D. R. Schmatz et al.

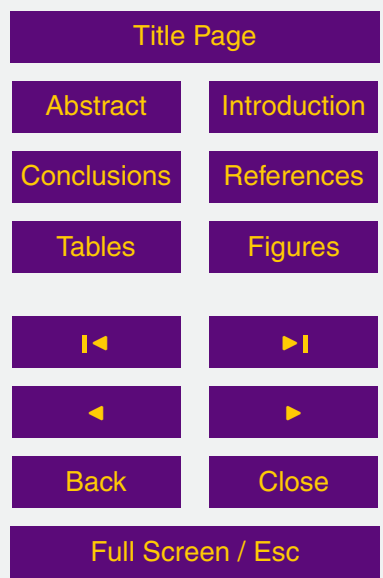

Printer-friendly Version

Interactive Discussion 
we assumed physical processes like air pressure, weather patterns, exposition, and geographic trends in solar radiation are unaffected by the exposure of additional terrestrial land area during LGM. Second, current climate should be extended to the LGM shoreline and, by doing so, current near-coast climate patterns should be replaced by 5 patterns resembling inland climate. This is important because the current near-coast climate is different from more inland climate due to effects of coast proximity. Third, the constructed baseline climate data that covers areas between the current and LGM coastlines should be consistent with the observed regional climate regimes and, thus, should not present climates that are obviously novel from a regional perspective.

Given these priorities, our objectives for the construction of a climate baseline by extension of current climates to areas that are now inundated and were exposed during the LGM emphasized avoidance and minimization of climate artefacts and included: (i) use of all available information, including data on observed, high resolution current climate and reconstructed coarse resolution climate of Europe over the past 500 years, elevation, latitude, longitude, and the empirical dependencies among these quantities themselves, (ii) avoidance of artefacts, such as visually detectable remnants of patterns of current coastal climate, and artefacts that might arise from the extrapolation techniques themselves, and (iii) avoidance of unrealistic values (e.g., negative values of precipitation) that might arise by uncritical extrapolation of current geographic trends or during spatial interpolation of climates of small islands currently far offshore. To this end, we developed two different approaches for temperature and precipitation, which are explained in detail below.

\subsection{Temperature}

Temperature strongly scales with changes in elevation, and these lapse rates vary con25

siderably among regions. One way of scaling temperature data is to apply a multiple lin-
ear regression (MLR) in order to explain variation in temperature by means of elevation, longitude and latitude. Performing MLRs in a moving window allows for reconstructing the spatial variation in elevational and lateral lapse rates. Such lapse rates can then be 2590

\section{CPD}

11, 2585-2613, 2015

High resolution climate data from 5 GCMs of LGM

D. R. Schmatz et al.

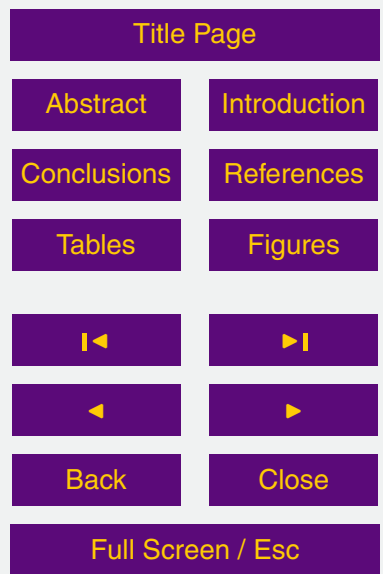

Printer-friendly Version

Interactive Discussion 
extrapolated from the current to the LGM coastline. Here, we are interested in developing the elevational and lateral lapse rates ways that obviate the inclusion of coastal areas (e.g. all area near coasts lower than 20 ma.s.l.), so as to avoid spurious effects when extrapolating from land that would not have near-coast climate at LGM times. 5 On the other hand, we use only as much land in the proximity of coasts as necessary for development of elevational and lateral lapse rates in order to avoid unnecessarily intense computations. To do so, we restrict the MLR calculations to areas that are fairly proximal to coasts, and we perform the MLR calculations at a 2.5 arc minute resolution, which is coarser than the original grid resolution for baseline temperatures (30 s). 10 In this sub-chapter we illustrate (Fig. 1a) and list (Fig. 1b) the main processing steps and present the developed method (Fig. 2).

\subsubsection{Multiple linear regression within a moving window}

While non-linear approaches to downscaling LGM climate in Europe have been used (Korhonen et al., 2014), a useful avenue for constructing baseline climate for areas 5 currently lacking terrestrial climate is multiple linear regression (MLR) in a distance dependent way (Stahl et al., 2006), using elevation from a digital elevation model (DEM), latitude (LAT) and longitude (LON) as predictor variables of temperature (Eq. 1):

$T=\beta_{0}+\beta_{1} \times \mathrm{DEM}+\beta_{2} \times \mathrm{LAT}+\beta_{3} \times \mathrm{LON}$,

where $T$ is the fitted temperature, $\beta_{0}$ the intercept, $\beta_{1}, \beta_{2}$ and $\beta_{3}$ are regression coefficients for geographic variables or elevation lapse rates. This MLR is solved and the regression parameters $\beta_{0}, \ldots, \beta_{3}$ are estimated using DEM, LAT and LON values from an area surrounding each focal pixel.

To estimate regression parameters for a gridded study area we defined a window of 25 by 25 cells that was moved column-by-column and row-by-row. This was done simultaneously over the grids of the climate variable of interest (e.g. average temperature of a certain month) and the three predictor variables. At every window position, all

\section{CPD}

$11,2585-2613,2015$

High resolution climate data from 5 GCMs of LGM

D. R. Schmatz et al.

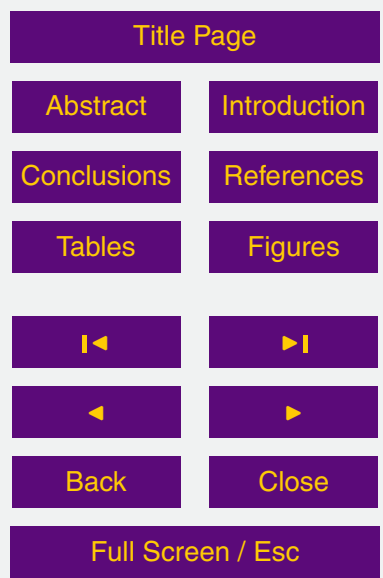

Printer-friendly Version

Interactive Discussion 
grids ( $T$, DEM, LAT, LON) were sampled and the MLR was applied. The four regression parameters $\beta_{0}$ to $\beta_{3}$ were saved in four new grids that store the result from each moving window regression at the position of the centre cell of the window.

We used 2.5 arc minute resolution temperature grids and the DEM that were avail5 able from the Worldclim website (downloaded on 22 March 2010). In this data set, only grid cells representing land areas contain data while ocean cells are empty. The window size of $25 \times 25$ cells, resulting in a maximum of 625 cells per window, ensured that the influence of latitude and longitude was detected during MLR. In order to mask out current coastal climate (Fig. 1a), we only conducted MLR with data from cells with ele10 vations of $20 \mathrm{~m}$ and higher (step 1 in Fig. 1b), essentially creating an exclusion mask, the width of which depended on topography. The mask was wide in flat regions (e.g. in the Netherlands) and narrow on steep coasts (e.g. Norway). Since cells without data (e.g. ocean pixels surrounding a peninsula) could not contribute to the regression, we established an empirical threshold of 170 data-containing cells as the necessary minimum number for calculating the lapse rate of the centre cell (Fig. 1a). This number ensured that there were sufficient data to conduct MLR and that the centre cell never lay far to the seaward side of the coast. Since the inland climate was kept unaltered (i.e. held original Worldclim values), corresponding regression calculations were unnecessary. We prevented calculation over terrestrial pixels far inland by limiting the maximum number of data-bearing cells within a window to 624. This assured MLR was only calculated along the coasts (red shaded area, Fig. 1a; step 2, Fig. 1b), and excepted areas excluded by the $20 \mathrm{~m}$ elevation threshold and the 170 cell minimum. Near to coasts, the number of cells that were used to construct the MLR varied regionally (Fig. 2a), as did elevational lapse rates ( $\beta_{1}$ from Eq. 1$)$ stored to the centre cells of moving windows 25 (Fig. 2b).

\subsubsection{Extension of temperature to the LGM coast line}

In a next step, the areas between the current and LGM coasts that originally contained no climate data (i.e., currently in the ocean) and the region for which MLR parameters

\section{CPD}

11, 2585-2613, 2015

High resolution climate data from 5 GCMs of LGM

D. R. Schmatz et al.

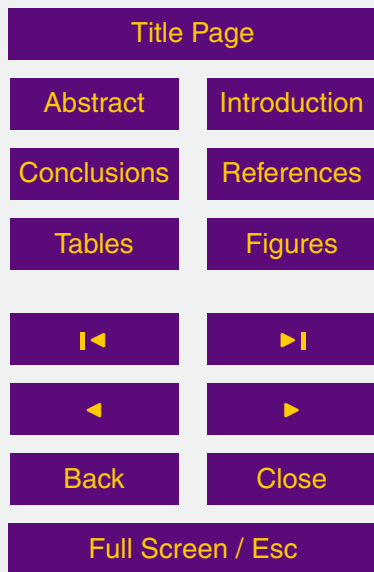

Printer-friendly Version

Interactive Discussion 
were available (red shaded region in Fig. 1a) needed to be filled. We used the "poisson_grid_fill" function of National Center for Atmospheric Research's (NCAR) Command Language NCL (NCL, 2013) to extrapolate MLR parameters $\beta_{0}-\beta_{3}$ (Fig. 2c for $\beta_{1}$, step 3 in Fig. 1 b) to these empty grid cells. This function derives these values by 5 solving Poisson's equation via relaxation (Varga, 2009). The input values within the region used to calculate MLRs in moving windows were left unchanged and acted as boundary conditions (Fig. 2c).

The filled $\beta_{0}-\beta_{3}$ grids were then interpolated to the desired high resolution of 30 arc $s$ using bilinear interpolation (step 4 in Fig. 1b). Finally, the high resolution $\beta_{0}$ to $\beta_{3}$ 10 grids were used together with a high resolution DEM of the ocean floor to recalculate the temperature at each grid cell using Eq. (1). The elevations for currently submerged areas were taken from the General Bathymetric Chart of the Oceans (http://www.gebco.net; the GEBCO_08 Grid version 20100927 ), which is a global 30 arcs grid (Becker et al., 2009). We removed all cells in the ocean off the LGM coast using the shoreline position of continental Europe at LGM (adapted according to https://pmip3.Isce.ipsl.fr/share/design/ice_bc/pmip3_21k_sftlf_v0.nc from P. Bartlein, unpublished data derived from Ehlers and Gibbard (2004); Peltier (2004); see step 5 , Fig. 1b). Finally, we reset the values of cells with elevations above $20 \mathrm{~m}$ to the original values of the Worldclim 30 arc s grid to obtain "Worldclim extended" monthly climate grids (step 6, Fig. 1b). These grids represent today's terrestrial climate assuming an LGM coastline, and form the baseline climate with which to reconstruct LGM climates. We applied this technique to downscale monthly average temperatures $\left(T_{\text {ave }}\right)$, and additionally monthly minimum $\left(T_{\min }\right)$ and maximum temperatures $\left(T_{\max }\right)$ because of their usefulness in constructing additional derived variables for study of climate change im25 pacts.

\subsubsection{Evaluation of temperature extrapolations}

We sought to evaluate the implemented method by comparing the results to existing data. To estimate the extrapolation error, we extrapolated the MLR coefficients onto

\section{CPD}

$11,2585-2613,2015$

High resolution climate data from 5 GCMs of LGM

D. R. Schmatz et al.

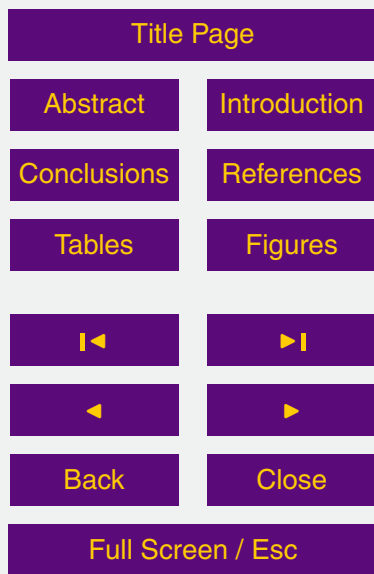

Printer-friendly Version

Interactive Discussion 
the continental terrestrial area and recalculated temperature at each grid cell using the original Worldclim DEM. This allowed us to compare the recalculated temperatures to the original Worldclim values. Instead of testing individual months, we compiled the monthly data into a single dataset. We established five distance zones of 1 arc degree 5 width from the coast inwards (Fig. 3) and calculated residuals as the difference between the predicted temperatures and those of the original Worldclim temperature layers. We restricted the elevation range to between 20 and $150 \mathrm{~m}$, which is similar to the elevation range we used in extrapolating temperatures to the LGM coastline ( $>20$ to $-120 \mathrm{~m}$ ). Lapse rates calculated from the regression were expected to be most accurate for 10 the area that is within the moving window region (red shaded region, Fig. 1a). We anticipated that the temperature predictions would be less reliable the farther they were extended inland from the sampled area crossed by the moving window.

\subsubsection{Adjustment for current to preindustrial temperature differences}

We used a time series of reconstructed monthly $T_{\text {ave }}$ (Luterbacher et al., 2004; Xo15 plaki et al., 2005) to account for temperature differences between preindustrial climate conditions used as a baseline for GCM simulations (around 1750; http://pmip2.Isce. ipsl.fr/design/boundary.shtml) and the calibration period for producing the Worldclim climate data (1950-2000), which represents current climate conditions. We applied the change factor method to make this adjustment. First we calculated the 50 year monthly

20 $T_{\text {ave }}$ for $1725-1775$ (preindustrial $1750 \pm 25$ years) and also for 1950-2000 (current conditions) and then their difference (preindustrial-current). We again used the "poisson_grid_fill" function (NCL, 2013) to fill the target areas of these anomalies holding no data, interpolated them to 30 arc s using bilinear interpolation, then added them to $T_{\text {ave }}$ of "Worldclim extended" to obtain $T_{\text {ave }}$ of "preindustrial Worldclim extended", monthly 25 climate grids representing preindustrial $T_{\text {ave }}$ within the LGM coastline (Fig. 2d; step 7 in Fig. 1b). To construct baseline values for $T_{\min }$ and $T_{\max }$ we had to apply the interpolated $T_{\text {ave }}$ anomalies to $T_{\min }$ and $T_{\max }$ of "Worldclim extended" because reconstructed $T_{\min }$ and $T_{\max }$ were not available for preindustrial times, thus these anomalies could not 2594

\section{CPD}

$11,2585-2613,2015$

High resolution climate data from 5 GCMs of LGM

D. R. Schmatz et al.

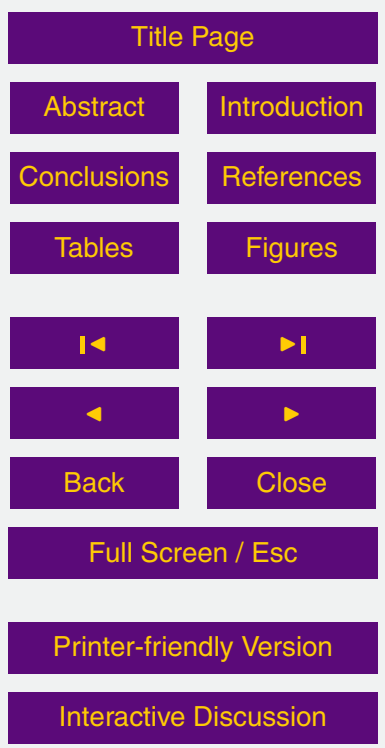


be calculated. We assumed negligible differences existed between the anomalies of $T_{\text {ave }}$ and those of $T_{\min }$ and $T_{\max }$ but had no means of testing this assumption. The values for the three temperature variables were subsequently used as the high-resolution pre-industrial baseline climate to downscale the values from the GCM simulations.

\section{$5 \quad 2.2$ Precipitation}

Even though we intended to present downscaled climate data for Europe we used the area of the Yucatán Peninsula (Gulf of Mexico) to develop our method to extend Worldclim precipitation grids to the LGM coastline. Yucatán seemed especially well suited because of the variation in precipitation gradients in this area and the great expansion of terrestrial area that occurred during glacial periods. First, we tested an approach to downscaling precipitation data that was identical to the approach we used to downscale temperature. Because this extrapolation resulted in unrealistic values due to both strong local precipitation gradients and effects from small remote islands, we subsequently explored direct extrapolation of precipitation to the LGM coastline as a means to construct the necessary baseline conditions.

\subsubsection{Extension of precipitation to the LGM coast line}

In order to retain the large-scale precipitation regime, we created a coarse scale grid of 1 arc degree resolution by aggregation from the Worldclim 30 arc s resolution data (step 1 in Fig. 1d). We averaged all available cell values while ignoring cells without data. We then filled all 1 arc degree cells without data (i.e., ocean) using the "gdal_fillnodata" function, an inverse distance weighted interpolation algorithm implemented in a python script (Fig. 1c; www.gdal.org; GDAL Development Team, 2013). The original 30 arc s grid and the new 1 deg grid were then both converted to points (steps 2 and 3, Fig. 1d) and merged into a single file as input for the spatial interpolation (Fig. 1c; step 5, 25 Fig. 1d). We evaluated several interpolation methods, all tested on this merged point file

\section{CPD}

$11,2585-2613,2015$

High resolution climate data from 5 GCMs of LGM

D. R. Schmatz et al.

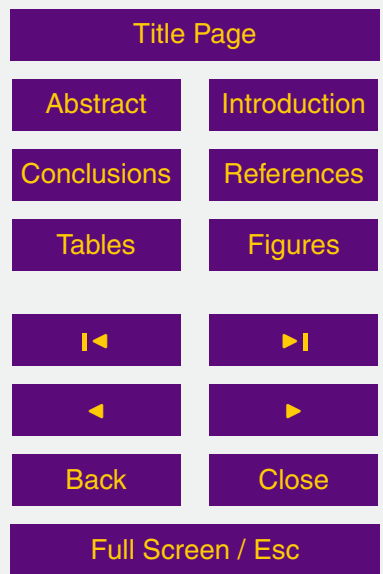

Printer-friendly Version

Interactive Discussion 
(Fig. A1a) and finally selected the natural neighbour method in subsequent analyses. To further improve the result we filtered the input data as follows.

In order to avoid apparent interpolation artefacts originating from small offshore islands, we applied a 9-point smoothing filter to the 1 arc degree grids prior to interpola5 tion. This filter calculated a weighted average of each grid point with respect to the 8 surrounding neighbours. The centre point received a weight of 1.0 , the points $N, S, E$, W a weight of 0.5 and the points NE, NW, SE, SW a weight of 0.3. (step 2 in Figs. 1d, 4a).

To avoid artefacts that could arise from extrapolating inland climate over coastal cli10 mate to the LGM coastline we established the same variable width mask as we did for temperature within the current coastal line. The mask was defined as the area with an elevation lower than 20 ma.s.l. (step 4 in Figs. 1d, 4a). This mask varied in width, similar to the temperature mask, above. In order to avoid spurious effects from isolated pixels, we additionally applied a boundary cleaning filter in ArcGIS (ESRI, 2013), 15 which smoothed the mask's boundary. All data points within the mask (of land below 20 ma.s.l.) were removed from the 30 arc s Worldclim data prior to merging with the smoothed 1 arc degree grid points (Fig. 4a). These merged points were then spatially interpolated to the native Worldclim 30 arc $s$ resolution using the natural neighbour method (step 6 in Figs. 1d, 4b). In the step to obtain "Worldclim extended" current climate grids, we removed all cells in the ocean beyond the shoreline position at LGM and we replaced all cells inland of the $20 \mathrm{~m}$ elevation mask with the original Worldclim values (not shown; step 7 in Fig. 1d). After developing this method on the Yucatán Peninsula, we applied it to the region of Europe. For precipitation, we could not correct for differences between preindustrial and current climate due to missing data. Thus, there is no "preindustrial Worldclim extended" for precipitation prior to combining it with reconstructed LGM climate anomalies. We therefore have to assume that the precipitation difference between current and preindustrial times is negligible.

\section{CPD}

$11,2585-2613,2015$

High resolution climate data from 5 GCMs of LGM

D. R. Schmatz et al.

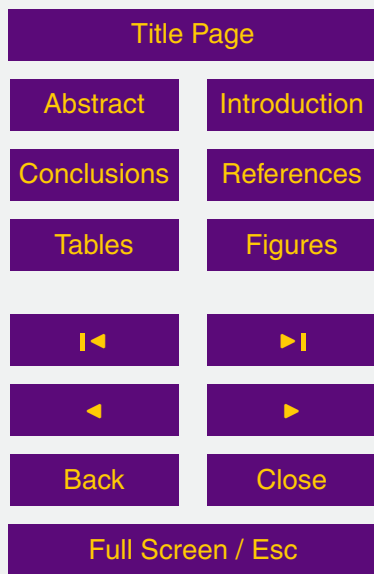

Printer-friendly Version

Interactive Discussion 


\subsection{Downscaling 5 GCMs}

After producing extended layers for current and preindustrial climates, we downscaled data from five GCM simulations of climate at the LGM over the full extent of Europe. Data were downloaded from the PMIP2 database (Braconnot et al., 2007) for

5 the following GCMs: CCSM, CNRM, FGOALS, IPSL-CM4, MIROC3.2. Each of these GCMs simulated data for one hundred model years under the conditions and constraints of both the LGM and the preindustrial period (around 1750). First we calculated monthly averages for each of the GCMs for these two time periods. Then, the LGM monthly data sets were expressed as anomalies relative to the preindustrial monthly data sets. We calculated difference anomalies for minimum, maximum and average temperature $\left(T_{\text {anomaly }}=T_{\mathrm{LGM}}-T_{\text {preindustrial }}\right)$ but relative anomalies for precipitation $\left(\mathrm{Prec}_{\text {anomaly }}=\left[\mathrm{Prec}_{\mathrm{LGM}}-\mathrm{Prec}_{\text {preindustrial }}\right] / \mathrm{Prec}_{\text {preindustrial }}\right)$ in order to avoid creation of negative precipitation during LGM. The resulting anomaly maps were then interpolated to $a 30$ arc s resolution using bilinear interpolation. In the final step the anomalies were 15 combined with the high-resolution baseline climate to yield the final high-resolution maps: temperature anomalies were added to "preindustrial Worldclim extended" while precipitation anomalies were multiplied by "Worldclim extended". Figure 5 illustrates for the arbitrarily chosen month May of CCSM the current temperature and precipitation of Worldclim and the reconstructed values at LGM.

\section{Results and discussion}

\subsection{Temperature}

The moving window technique is constrained to areas close to (but not at) the coast (elevation $>20 \mathrm{~m}$, selection of maximum cells per window). As expected, the standard error increases with distance from the coast (Table 1; Fig. 6). Under the assumption that the extrapolation into the ocean produces the same result, we would expect an

\section{CPD}

$11,2585-2613,2015$

High resolution climate data from 5 GCMs of LGM

D. R. Schmatz et al.

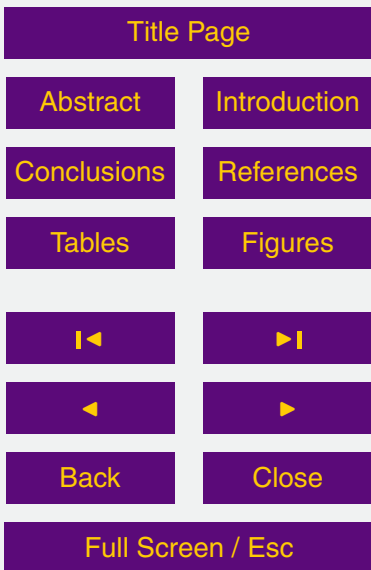

Printer-friendly Version

Interactive Discussion 
error range from $0.3^{\circ} \mathrm{C}$ close to the coast (zone 1) to about $0.7^{\circ} \mathrm{C}$ at the furthest extrapolated region in the central North Sea (about zone 3). Overall, coastal areas are well represented, with a minimum of error in this exercise. This validation suggests that the terrestrial coastal areas at LGM, which are not farther to the seaside from the 5 current coast line than 2 arc degrees, show no distance effect from interpolations, and only a marginal increase in error when situated further away than 2 arc degrees (i.e. ca. $200 \mathrm{~km})$.

One issue is that the minimum and maximum number of cells per window were empirically chosen. This choice influences MLR estimation. If the minimum number is 10 too small, there may be an insufficient number of points available for robust regression estimation of lapse rates. Also, the centre cell may lie far offshore and the regression would then be based exclusively on a few coastal pixels. On the other hand, if the minimum number is set too large, narrow peninsulas that extend far to sea (e.g. Land's End, Cornwall, UK) may provide too few pixels to qualify for inclusion in the regression.

15 Thus, the extrapolation would start relatively far inland and the potential effects on estimation of temperature lapse rates by the high ground of the peninsula would not be represented.

We tried alternative algorithms to extrapolate the slope coefficients to the LGM coast. The "poisson_gridfill" function performs well when the area to be filled is bounded by valid data (e.g. North Sea, Mediterranean Sea). When extrapolating into unbounded regions (e.g. towards distant shelf rim of northern North Sea) "gdal_fillnodata" performs better at greater distances than "poisson_gridfill", but produces streaky patterns that would have required subsequent smoothing.

\subsection{Precipitation}

25 Initial attempts to create base period data within the LGM coastline by using lapse rates and the moving window method did not provide acceptable results because the extrapolated MLR coefficients of both simple and multiple linear regressions often produced unrealistic negative precipitation values. In this case, dependency of precipitation on 2598

\section{CPD}

$11,2585-2613,2015$

High resolution climate data from 5 GCMs of LGM

D. R. Schmatz et al.

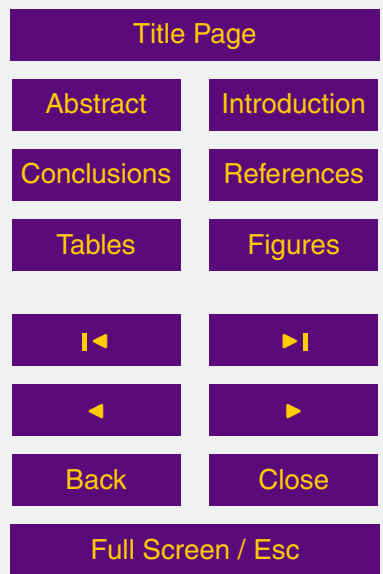

Printer-friendly Version

Interactive Discussion 
elevation, latitude, and longitude could not be used. This was due to propagation of geographic trends that are induced by current coastal climate patterns, as presented by Worldclim grids, and by tiny islands far offshore with partly quite distinct climates (Fig. A1).

The pattern that resulted from direct interpolation with "gdal_fillnodata" was noisy, and two tiny islands northwest of Yucatán in our example (the circled dark red pixels in Fig. A1a), which were each represented by only two adjacent pixels in the original 30 arc s grid, substantially influenced values of the $1^{\circ}$ grid (Fig. A1a). The influence of the islands is barely noticeable after applying a 9-point smoothing filter (Fig. 4a). When 10 left unsmoothed, these islands influenced precipitation patterns independent of various methods of interpolation (Fig. A1). In our comparison, these methods varied in the quality of their results. Inverse distance weighting produced a patchy pattern (Fig. A1b), while use of splines produced artefacts along the border to the 30 arc $s$ resolution points (Fig. A1c). The natural neighbour interpolation method produced a smooth result with 15 minimal artefacts (Fig. A1d) and was chosen as the final method.

Application of the variable distance mask eliminated most artefacts of the current coast, producing a smooth extrapolation to the LGM coastline North from the Yucatán peninsula and retained all information along steep coasts. The boundary cleaning filter effectively produced a smoothed and clear zone boundary of the selected elevations above $20 \mathrm{~m}$, and further reduced the effects of islands in the Gulf of Mexico that lie just off the current northeast coast of the Yucatán (compare Fig. $4 \mathrm{~b}$ to A1d). Precipitation was not corrected for recent climate change to preindustrial conditions simply due to missing data.

\subsection{Uncertainties}

25 In this study we combine four different data sets, which are based on measured or modelled data. Thus, there are several possible sources of errors that may affect our final results. Errors may stem from, for example, the measured values and the interpolation algorithm used to create Worldclim (Hijmans et al., 2005), the GCMs (Braconnot et al.,

\section{9}

\section{CPD}

$11,2585-2613,2015$

High resolution climate data from 5 GCMs of LGM

D. R. Schmatz et al.

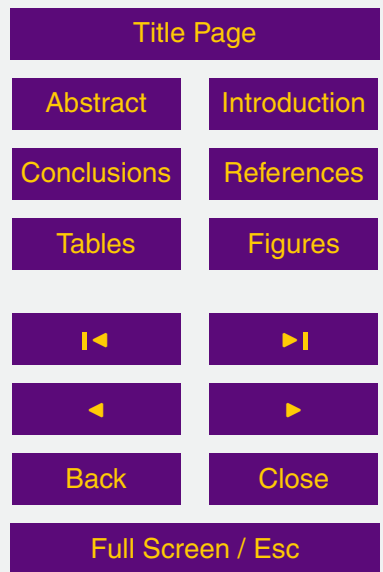

Printer-friendly Version

Interactive Discussion 
2007), the change factor method (Anandhi et al., 2011), the reconstructed monthly $T_{\text {ave }}$ (Luterbacher et al., 2004; Xoplaki et al., 2005), the bathymetric data (Becker et al., 2009) and, of course, the methods developed in this study as discussed above. While we cannot test for possible errors originating from the interpolation of the precipitation

5 values, we interpolated temperature values towards the continent interior generated interpolation errors and compared these value to those of the original Worldclim maps (Figs. 3 and 6). We found that the absolute error is less than $1{ }^{\circ} \mathrm{C}$ for $98.9 \%$ of the pixels in the first two 1 arc degree distance zones (96.6\% in the first three zones, Fig. 6). The first two zones cover most of the regions used for interpolations. $91.4 \%$ of the pixels in 10 the first $1^{\circ}$ zone revealed an error of less than $0.5^{\circ} \mathrm{C}(87.8$ and $83.0 \%$ of the pixels in the first two and three zones, respectively).

\subsection{Need for downscaled GCMs of the LGM}

The high-resolution monthly temperature and precipitation grids offer new possibilities in the use of niche/vegetation/migration models. However, the empirical character of 15 the proposed procedures has to be considered in such applications. The temperatures $\left(T_{\text {ave }}, T_{\min }\right.$ and $\left.T_{\max }\right)$ are corrected for recent climate change since the preindustrial time period but precipitation is not. This may introduce inconsistencies. In addition, we assumed that the temperature anomaly for $T_{\text {ave }}$ equals those of $T_{\min }$ and $T_{\max }$, which may have introduced additional uncertainties.

20 The use of GCM data to study the paleo distribution of species is an important aspect of paleoecology (Maiorano et al., 2013; Nogues-Bravo, 2009). However, the relevance of data resolution to the modeling of climate impacts on biodiversity remains unclear (Guisan et al., 2007; Randin et al., 2009). Downscaled GCM simulations of LGM climate have proven important in estimating the precise locations of potential refugia with 25 suitable climates for species during the LGM (Bryson et al., 2014; Patsiou et al., 2014; Schorr et al., 2012, 2013). The approaches developed here provide the means to easily downscale a greater number of GCM simulations, which can facilitate the evaluation of uncertainties in studies of the impacts of climate change over periods that involve

\section{CPD}

11, 2585-2613, 2015

High resolution climate data from 5 GCMs of LGM

D. R. Schmatz et al.

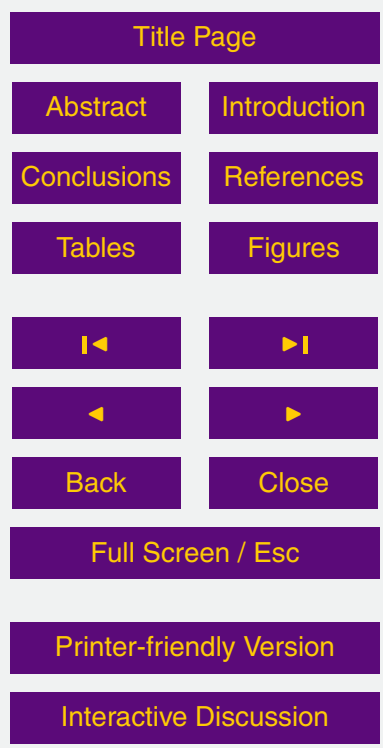


changing sea levels through the use of ensemble modeling approaches (Araujo and New, 2007). Further, the transparency provided by full description of the downscaling procedure, as we have presented here, should facilitate the evaluation of the results from studies of climate impacts that have used the resulting high-resolution data.

\section{Summary and conclusions}

Here, we present a straightforward method to downscale coarse resolution GCM data of the last glacial maximum to a very high spatial resolution using the delta change method. In this approach, we account for differing and varied coast lines using a moving window method, combined with extrapolation techniques, and also bridge the gap 10 between preindustrial to modern times using the same delta change method for temperature. The proposed moving window method predicts temperature using a linear relationship of the explanatory variables elevation, latitude and longitude. The coefficients resulting from a multiple linear regression (MLR) in a moving window technique are extrapolated to the LGM coastlines and are then used to predict temperatures at 15 the new positions. Precipitation is directly extrapolated to the LGM coastline. This documentation of the downscaling of climate data to coastal areas should support efforts to identify potential impacts of climate change around the time of the LGM. All data for Europe produced in the course of this study, including additional variables for ecological modelling, can be accessed at the PANGAEA repository. As additional variables we calculated 19 "bioclimatic" variables following the algorithms of Hijmans et al. (2005), which are often used in climate change impact studies on biological diversity (Hijmans et al., 2005).

\section{Appendix: Selection of interpolation method}

To interpolate precipitation we evaluated several methods, all tested on the merged 25 point file (Fig. A1a). These include (i) inverse distance weighting (Fig. A1b; Philip and

\section{CPD}

$11,2585-2613,2015$

High resolution climate data from 5 GCMs of LGM

D. R. Schmatz et al.

\section{Title Page}

Abstract Introduction Conclusions References Tables Figures

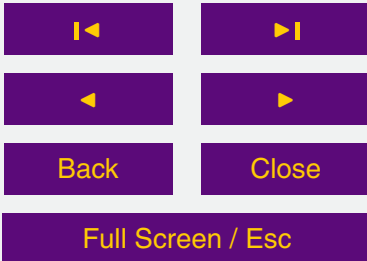

Printer-friendly Version

Interactive Discussion 2601 
Watson, 1982; Watson and Philip, 1985), (ii) splines with tension (Fig. A1c; Franke, 1982; Mitas and Mitasova, 1988), and (iii) the natural neighbour method (Fig. A1d; Sibson, 1981; Watson, 1992). We selected the natural neighbour method in subsequent analyses.

5 Acknowledgements. We acknowledge the international modelling groups for providing their data for analysis, the Laboratoire des Sciences du Climat et de l'Environnement (LSCE) for collecting and archiving the model data, and www.worldclim.org for providing high resolution climate data. The PMIP 2 Data Archive is supported by CEA, CNRS and the Programme National d'Etude de la Dynamique du Climat (PNEDC). The analyses were performed using ver10 sion 04 January 2013 of the database. More information is available on http://pmip2.Isce.ipsl.fr/.

\section{References}

Anandhi, A., Frei, A., Pierson, D. C., Schneiderman, E. M., Zion, M. S., Lounsbury, D., and Matonse, A. H.: Examination of change factor methodologies for climate change impact assessment, Water Resour. Res., 47, W03501, doi:10.1029/2010WR009104, 2011.

15 Araujo, M. B. and New, M.: Ensemble forecasting of species distributions, Trends Ecol. Evol., 22, 42-47, 2007.

Becker, J. J., Sandwell, D. T., Smith, W. H. F., Braud, J., Binder, B., Depner, J., Fabre, D., Factor, J., Ingalls, S., Kim, S. H., Ladner, R., Marks, K., Nelson, S., Pharaoh, A., Trimmer, R., Von Rosenberg, J., Wallace, G., and Weatherall, P.: Global bathymetry and elevation data at 30 arc seconds resolution: SRTM30_PLUS, Mar. Geod., 32, 355-371, 2009.

Braconnot, P., Otto-Bliesner, B., Harrison, S., Joussaume, S., Peterchmitt, J.-Y., Abe-Ouchi, A., Crucifix, M., Driesschaert, E., Fichefet, Th., Hewitt, C. D., Kageyama, M., Kitoh, A., Laîné, A., Loutre, M.-F., Marti, O., Merkel, U., Ramstein, G., Valdes, P., Weber, S. L., Yu, Y., and Zhao, Y.: Results of PMIP2 coupled simulations of the Mid-Holocene and Last Glacial Maximum - Part 1: experiments and large-scale features, Clim. Past, 3, 261-277, doi:10.5194/cp3-261-2007, 2007.

Bryson, R. W., Prendini, L., Savary, W. E., and Pearman, P. B.: Caves as microrefugia: pleistocene phylogeography of the troglophilic North American scorpion Pseudouroctonus reddelli, Bmc Evol. Biol., 14, doi:10.1186/1471-2148-14-9, 2014.

\section{CPD}

$11,2585-2613,2015$

High resolution climate data from 5 GCMs of LGM

D. R. Schmatz et al.

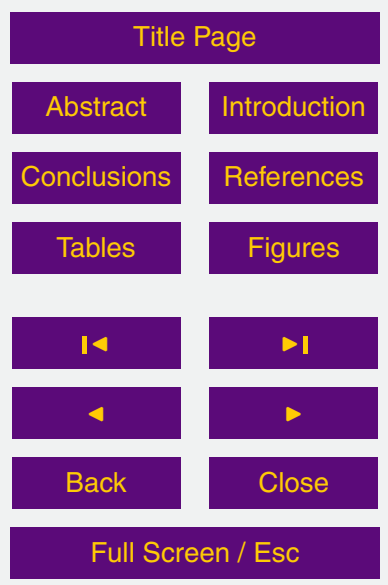

Printer-friendly Version

Interactive Discussion 
Buisson, L., Thuiller, W., Casajus, N., Lek, S., and Grenouillet, G.: Uncertainty in ensemble forecasting of species distribution, Glob. Change Biol., 16, 1145-1157, 2010.

Ehlers, J. and Gibbard, P. L.: Extent and Chronology of Glaciation, Volume 1: Europe, Elsevier Science, Amsterdam, 2004.

5 ESRI: ArcGIS Desktop, Environmental Systems Research Institute, Redlands, CA, USA, 2013.

Folland, C. K., Karl, T. R., Christy, J. R., Clarke, R. A., Gruza, G. V., Jouzel, J., Mann, M. E., Oerlemans, J., Salinger, M. J., and Wang, S.-W.: Observed climate variability and change, in: Climate Change 2001: The Scientific Basis, Contribution of Working Group I to the Third Assessment Report of the Intergovernmental Panel on Climate Change, edited by: Houghton, J. T., Ding, Y., Griggs, D. J., Noguer, M., v. d. Linden, P. J., Dai, X., Maskell, K., and Johnson, C. A., Cambridge University Press, Cambridge, UK, New York, NY, USA, 99181, 2001.

Franke, R.: Smooth interpolation of scattered data by local thin plate splines, Computer and Mathematics with Appllications, 8, 273-281, 1982.

GDAL Development Team: GDAL - Geospatial Data Abstraction Library, Open Source Geospatial Foundation, 2013.

Guisan, A., Zimmermann, N. E., Elith, J., Graham, C. H., Phillips, S., and Peterson, A. T.: What matters for predicting the occurrences of trees: techniques, data, or species' characteristics?, Ecol. Monogr., 77, 615-630, 2007.

20 Hijmans, R. J., Cameron, S. E., Parra, J. L., Jones, P. G., and Jarvis, A.: Very high resolution interpolated climate surfaces for global land areas, Int. J. Climatol., 25, 1965-1978, 2005.

IPCC: Climate Change 2014: Impacts, Adaptation, and Vulnerability, Part A: Global and Sectoral Aspects, Contribution of Working Group II to the Fifth Assessment Report of the Intergovernmental Panel on Climate Change, edited by: Field, C. B., Barros, V. R., Dokken, D. J., Mach, K. J., Mastrandrea, M. D., Bilir, T. E., Chatterjee, M., Ebi, K. L., Estrada, Y. O., Genova, R. C., Girma, B., Kissel, E. S., Levy, A. N., MacCracken, S., Mastrandrea, P. R., and White, L. L., Cambridge University Press, Cambridge, UK, New York, NY, USA, 2014a.

IPCC: Climate Change 2014: Impacts, Adaptation, and Vulnerability, Part B: Regional Aspects, Contribution of Working Group II to the Fifth Assessment Report of the Intergovernmental Panel on Climate Change, edited by: Barros, V. R., Field, C. B., Dokken, D. J., Mastrandrea, M. D., Mach, K. J., Bilir, T. E., Chatterjee, M., Ebi, K. L., Estrada, Y. O., Genova, R. C., Girma, B., Kissel, E. S., Levy, A. N., MacCracken, S., Mastrandrea, P. R., and White, L. L., Cambridge University Press, Cambridge, UK, New York, NY, USA, 2014b.

\section{CPD}

$11,2585-2613,2015$

\section{High resolution climate data from 5 GCMs of LGM}

D. R. Schmatz et al.

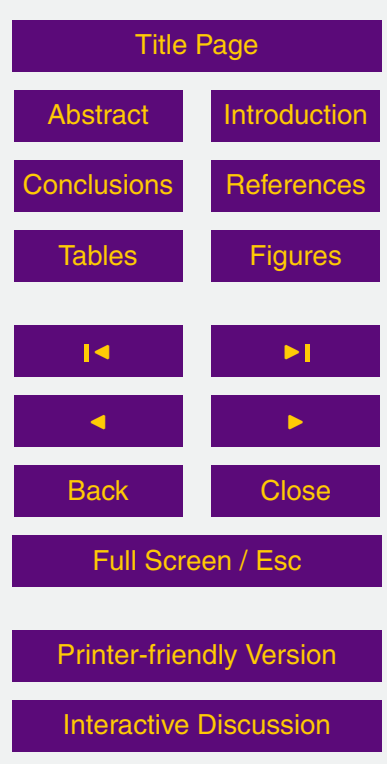

Interactive Discussion 
Korhonen, N., Venäläinen, A., Seppä, H., and Järvinen, H.: Statistical downscaling of a climate simulation of the last glacial cycle: temperature and precipitation over Northern Europe, Clim. Past, 10, 1489-1500, doi:10.5194/cp-10-1489-2014, 2014.

Luterbacher, J., Dietrich, D., Xoplaki, E., Grosjean, M., and Wanner, H.: European seasonal and 5 annual temperature variability, trends, and extremes since 1500, Science, 303, 1499-1503, 2004.

Maiorano, L., Cheddadi, R., Zimmermann, N. E., Pellissier, L., Petitpierre, B., Pottier, J., Laborde, H., Hurdu, B. I., Pearman, P. B., Psomas, A., Singarayer, J. S., Broennimann, O., Vittoz, P., Dubuis, A., Edwards, M. E., Binney, H. A., and Guisan, A.: Building the niche through time: using 13,000 years of data to predict the effects of climate change on three tree species in Europe, Global Ecol. Biogeogr., 22, 302-317, 2013.

Maraun, D., Wetterhall, F., Ireson, A. M., Chandler, R. E., Kendon, E. J., Widmann, M., Brienen, S., Rust, H. W., Sauter, T., Themessl, M., Venema, V. K. C., Chun, K. P., Goodess, C. M., Jones, R. G., Onof, C., Vrac, M., and Thiele-Eich, I.: Precipitation downscaling under climate change: recent developments to bridge the gap between dynamical models and the end user, Rev. Geophys., 48, RG3003, doi:10.1029/2009RG000314, 2010.

Mitas, L. and Mitasova, H.: General Variational Approach to the Interpolation Problem, Computer and Mathematics with Appllications, 16, 983-992, 1988.

NCL: The NCAR Command Language, National Center for Atmospheric Research UCAR/NCAR/CISL/VETS, Boulder, Colorado, 2013.

Nogues-Bravo, D.: Predicting the past distribution of species climatic niches, Global Ecol. Biogeogr., 18, 521-531, 2009.

Patsiou, T. S., Conti, E., Zimmermann, N. E., Theodoridis, S., and Randin, C. F.: Topo-climatic microrefugia explain the persistence of a rare endemic plant in the Alps during the last 21 millennia, Glob. Change Biol., 20, 2286-2300, 2014.

Pearman, P. B., Randin, C. F., Broennimann, O., Vittoz, P., van der Knaap, W. O., Engler, R., Le Lay, G., Zimmermann, N. E., and Guisan, A.: Prediction of plant species distributions across six millennia, Ecol. Lett., 11, 357-369, 2008.

Peltier, W. R.: Global glacial isostasy and the surface of the ice-age earth: the ice-5G (VM2) model and grace, Annu. Rev. Earth PI. Sc., 32, 111-149, 2004.

Philip, G. M. and Watson, D. F.: A precise method for determining contoured surfaces, Australian Petroleum Exploration Association Journal, 22, 205-212, 1982.

\section{CPD}

11, 2585-2613, 2015

High resolution climate data from 5 GCMs of LGM

D. R. Schmatz et al.

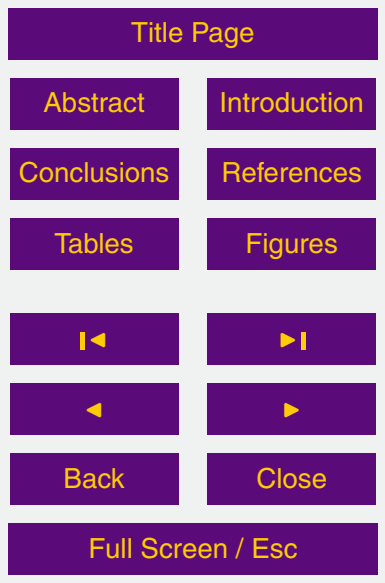

Printer-friendly Version

Interactive Discussion 
Randin, C. F., Engler, R., Normand, S., Zappa, M., Zimmermann, N. E., Pearman, P. B., Vittoz, P., Thuiller, W., and Guisan, A.: Climate change and plant distribution: local models predict high-elevation persistence, Glob. Change Biol., 15, 1557-1569, 2009.

Rosenberg, N. J., Blaine, B. L., and Shashi, V. B.: Microclimate: The Biological Environment, John Wiley \& Sons, New York, 1983.

Schorr, G., Holstein, N., Pearman, P. B., Guisan, A., and Kadereit, J. W.: Integrating species distribution models (SDMs) and phylogeography for two species of Alpine Primula, Ecology and Evolution, 2, 1260-1277, 2012.

Schorr, G., Pearman, P. B., Guisan, A., and Kadereit, J. W.: Combining palaeodistribution modelling and phylogeographical approaches for identifying glacial refugia in Alpine Primula, J. Biogeogr., 40, 1947-1960, 2013.

Sibson, R.: A brief description of natural neighbor interpolation, in: Interpolating Multivariate Data, John Wiley \& Sons, New York, Chapter 2, 21-36, 1981.

Stahl, K., Moore, R. D., Floyer, J. A., Asplin, M. G., and McKendry, I. G.: Comparison of approaches for spatial interpolation of daily air temperature in a large region with complex topography and highly variable station density, Agr. Forest Meteorol., 139, 224-236, 2006.

Thuiller, W., Lafourcade, B., Engler, R., and Araujo, M. B.: Biomod - a platform for ensemble forecasting of species distributions, Ecography, 32, 369-373, 2009.

Varga, R. S.: Matrix Iterative Analysis, Springer, Berlin, Heidelberg, 2009.

Watson, D. F.: Contouring: a Guide to the Analysis and Display of Spatial Data, Pergamon Press, London, 1992.

Watson, D. F. and Philip, G. M.: A refinement of inverse distance weighted interpolation, Geoprocessing, 2, 315-327, 1985.

Xoplaki, E., Luterbacher, J., Paeth, H., Dietrich, D., Steiner, N., Grosjean, M., and Wanner, H.: European spring and autumn temperature variability and change of extremes over the last half millennium, Geophys. Res. Lett., 32, L15713, doi:10.1029/2005GL023424, 2005.

\section{CPD}

$11,2585-2613,2015$

High resolution climate data from 5 GCMs of LGM

D. R. Schmatz et al.

\section{Title Page}

Abstract Introduction

Conclusions References

Tables Figures

14

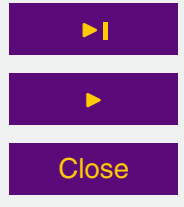

Full Screen / Esc

Printer-friendly Version

Interactive Discussion 
Table 1. Validation statistics of the difference between predicted temperatures calculated from the MLR coefficients extrapolated onto terrestrial areas and those of the original WorldClim layers. Only pixels within the elevation range between 20 and $150 \mathrm{~m}$ are included. See text and Fig. 3 for definition of the zones.

\begin{tabular}{crrrrrrrr}
\hline zone & $n$ pixels & Mean error & SD & $\min$ & 1st Q. & median & 3rd Q. & max. \\
\hline 1 & 27681564 & -0.022 & 0.322 & -2.888 & -0.276 & -0.022 & 0.229 & 4.526 \\
2 & 12939960 & 0.000 & 0.430 & -2.736 & -0.280 & 0.003 & 0.287 & 2.447 \\
3 & 8517852 & 0.087 & 0.685 & -3.755 & -0.286 & 0.120 & 0.485 & 2.841 \\
4 & 4472772 & 0.142 & 0.900 & -3.879 & -0.381 & 0.133 & 0.736 & 3.137 \\
5 & 7162500 & 0.485 & 1.051 & -3.227 & -0.202 & 0.439 & 1.215 & 4.552 \\
\hline
\end{tabular}

\section{CPD}

$11,2585-2613,2015$

High resolution climate data from 5 GCMs of LGM

D. R. Schmatz et al.

\section{Title Page}

Abstract

Introduction

Conclusions References

Tables

Figures

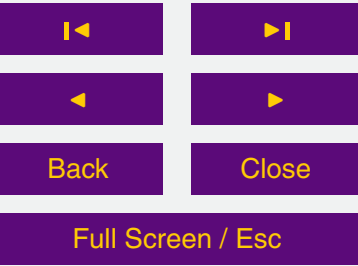

Printer-friendly Version

Interactive Discussion 


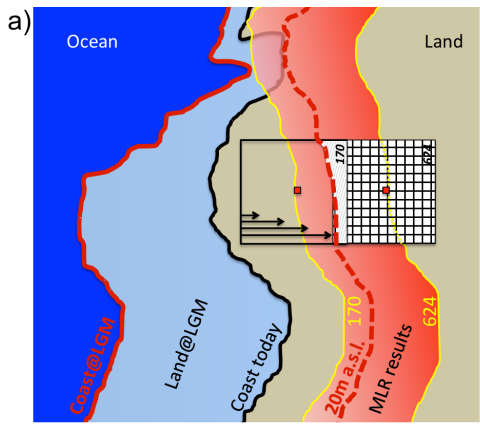

b)
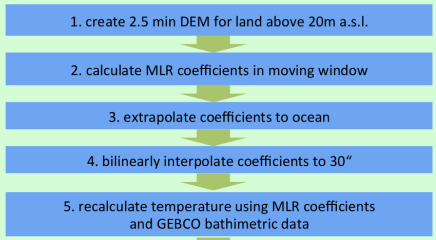

6. cut off result at LGM coast and replace cells above $20 \mathrm{~m}$ with original Worldclim values
oriast

7. apply change factor method to calculate preindustrial conditions using Luterbacher's reconstructions

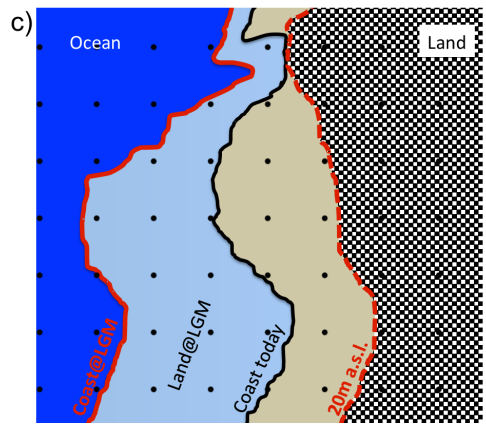

d) High resolution precipitation

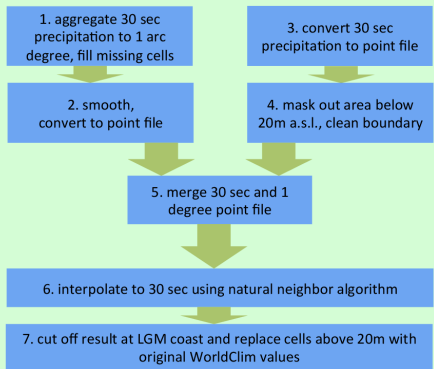

Figure 1. Illustration and flow charts of the methods for temperature (a, b) and precipitation (c, d). Current and LGM coastlines, and the 20 ma.s.l. contour line are shown. Both methods use only the area currently above $20 \mathrm{~m}$ elevation. (a) The multiple linear regression coefficients for the central cell are calculated when the moving window covers at least 170 cells above $20 \mathrm{~m}$, but no more than 624 cells. The resulting regression parameters are stored at the position of the center cell (red dots). The result area, i.e. center cells of all window positions, is shown in red. (b) Flow chart for the procedure that downscales temperature. (c) For the natural neighbor interpolation of precipitation, coarse scale $1^{\circ}$ grid points are used as input, in combination with the $30 \mathrm{~s}$ WorldClim points above 20 ma.s.l. (d) Flow chart for the procedure that downscales precipitation.
CPD

$11,2585-2613,2015$

\section{High resolution climate data from 5 GCMs of LGM}

D. R. Schmatz et al.

\section{Title Page}

Abstract Introduction

Conclusions References Tables Figures

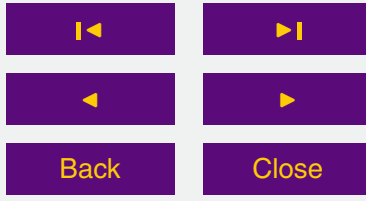

Full Screen / Esc

Printer-friendly Version

Interactive Discussion 

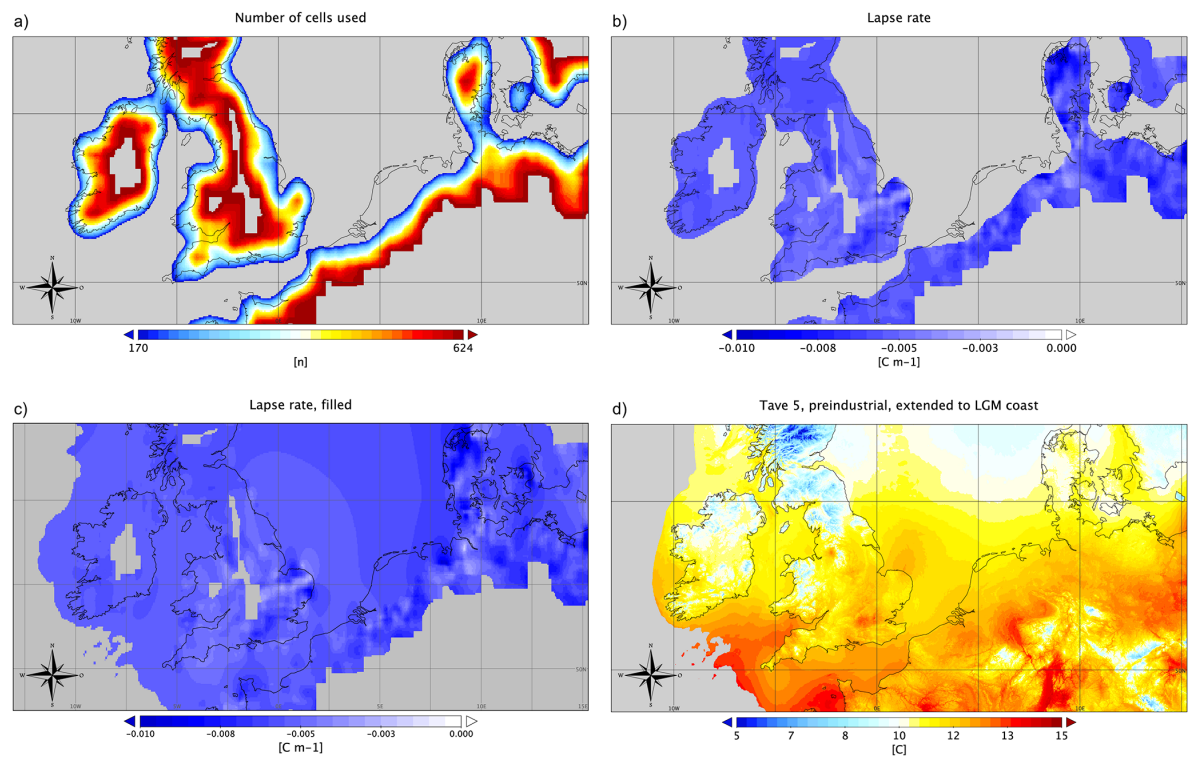

Figure 2. Illustration of steps in calculation of $T_{\text {ave }}$ of month 5 . Only northwestern Europe is shown and the current coastline is indicated for clarity. The maps show (a) the number of cells in each moving window used for the multiple linear regression (MLR) to estimate the regression coefficients for each focal pixel. Grey pixels were not calculated due to minimum and maximum thresholds and represent missing MLR coefficient data (see text). (b) The calculated regression coefficient $\beta_{1}$. (c) $\beta_{1}$ extrapolated to the LGM coast line with missing data filled using the "poisson_grid_fill" function, (d) "preindustrial Worldclim extended", the recalculated temperature using the estimated and interpolated regression coefficients with elevation data from the GEBCO_08 Grid. Original Worldclim values were reinserted for areas 20 ma.s.I. In a final step, values were corrected for recent change between pre-industrial and current climate.

\section{CPD}

$11,2585-2613,2015$

\section{High resolution climate data from 5 GCMs of LGM}

D. R. Schmatz et al.

\section{Title Page}

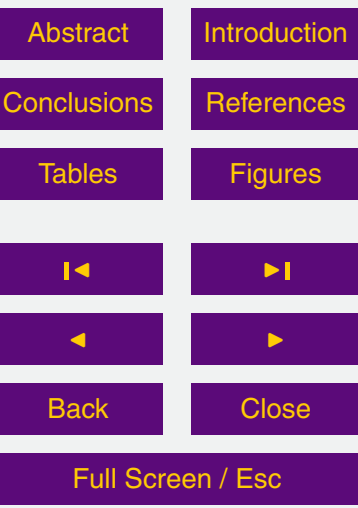

Printer-friendly Version

Interactive Discussion 


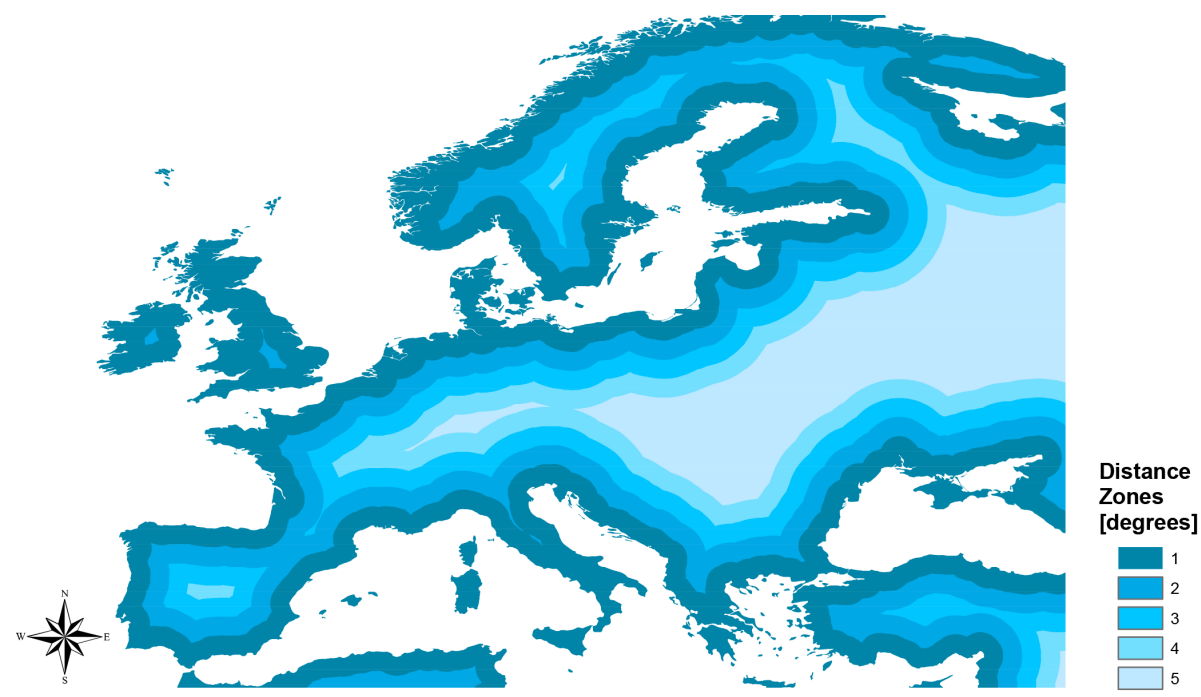

Figure 3. Five zones of distance (in degrees) from the current European coastline, each of 1 arc degree width.
CPD

$11,2585-2613,2015$

High resolution climate data from 5 GCMs of LGM

D. R. Schmatz et al.

\begin{tabular}{|c|c|}
\hline \multicolumn{2}{|c|}{ Title Page } \\
\hline Abstract & Introduction \\
\hline Conclusions & References \\
\hline Tables & Figures \\
\hline & \\
\hline 14 & $\triangleright$ \\
\hline 4 & $\checkmark$ \\
\hline Back & Close \\
\hline Full Screen / Esc
\end{tabular}

Printer-friendly Version

Interactive Discussion 

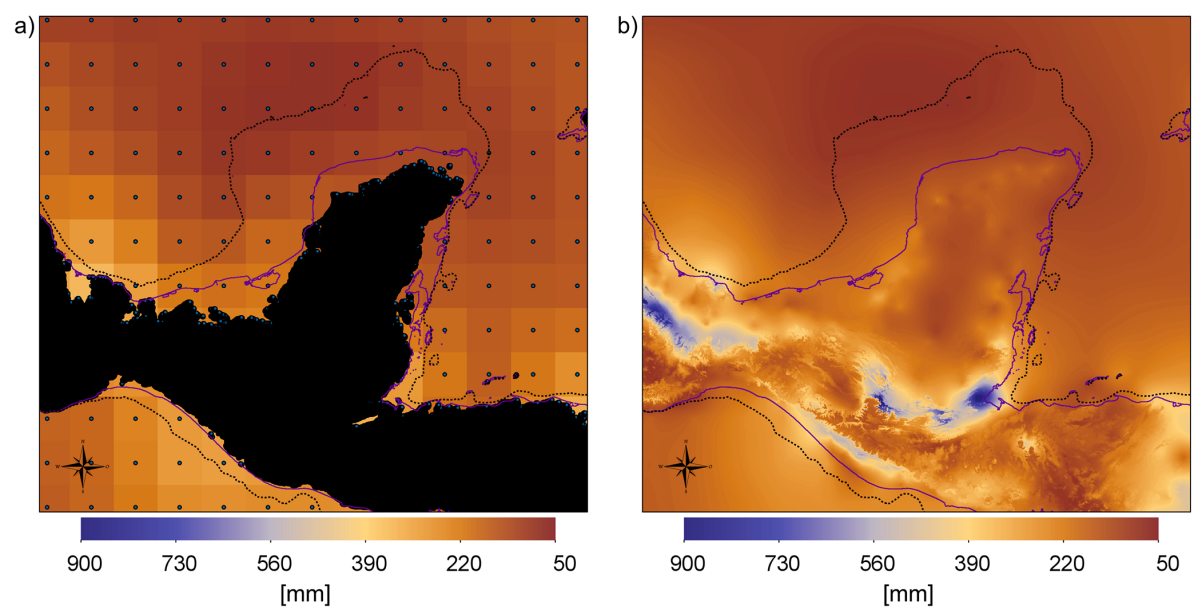

Figure 4. Application of an elevation buffer to terrestrial data with subsequent interpolation. The current coastline (solid) and the coast at the LGM (dotted) are shown for reference. Data represented are: (a) one arc degree points combined with 30 arc $s$ WorldClim-derived points from above the coastal mask of 20 ma.s.l. and cleaned using the boundary cleaning filter. Shaded colors are the smoothed coarse scale (1 arc degree) July precipitation grid; (b) interpolated July precipitation data from the previous panel, produced using the natural neighbor method.

\section{CPD}

$11,2585-2613,2015$

High resolution climate data from 5 GCMs of LGM

D. R. Schmatz et al.

\section{Title Page}

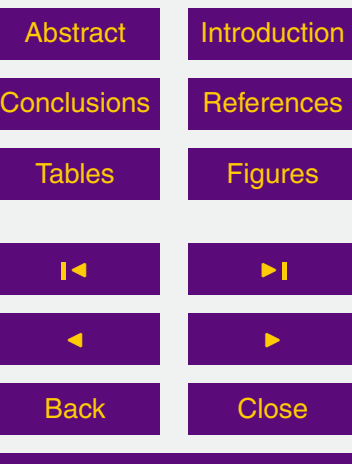

Full Screen / Esc

Printer-friendly Version

Interactive Discussion 

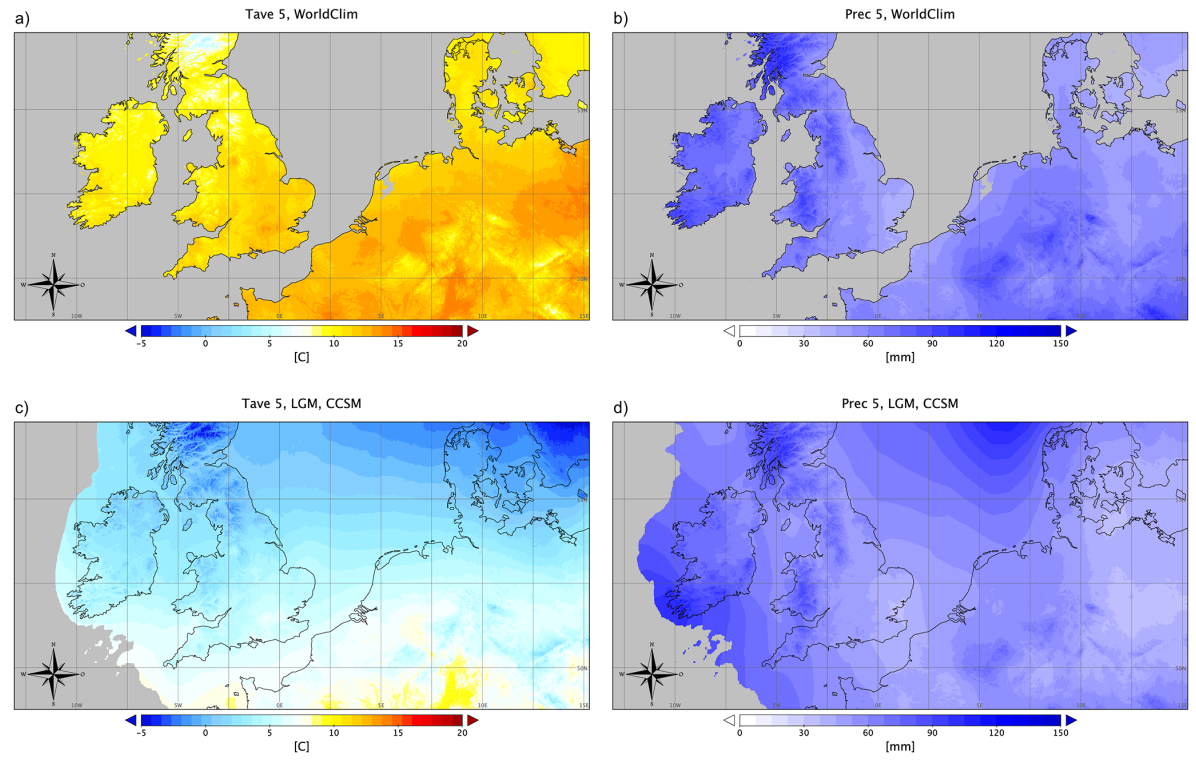

Figure 5. Illustration of temperature and precipitation for May. Maps (a) and (b) show current values and maps (c) and (d) the reconstructed LGM values.

CPD

11, 2585-2613, 2015

High resolution climate data from 5 GCMs of LGM

D. R. Schmatz et al.

\section{Title Page}

Abstract

Introduction

Conclusions

References

Tables

Figures

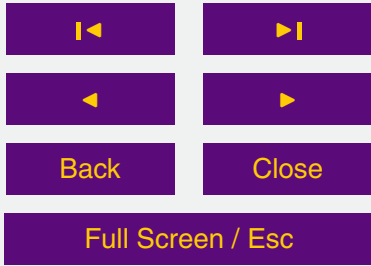

Printer-friendly Version

Interactive Discussion 
Interpolation errors, all months

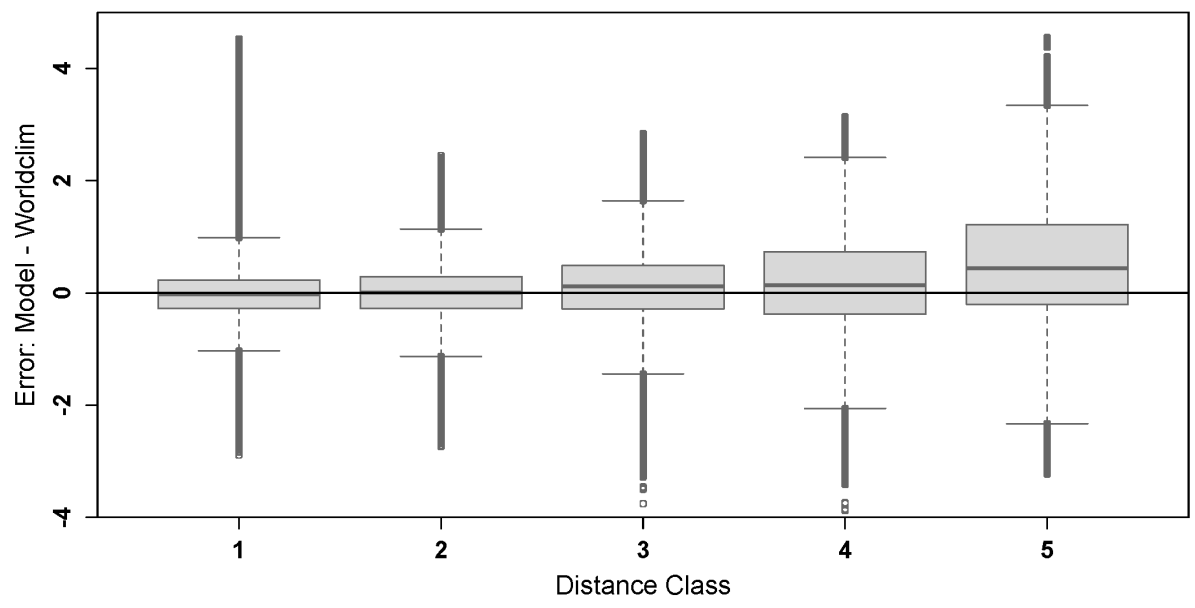

Figure 6. Boxplot of differences between predicted values for terrestrial values of temperature and WorldClim values for each distance zone of 1 arc degree (see Fig. 3). Elements show the median, first and third quartiles defining the box, the whiskers extending to 1.5 times the interquartile range from the box, and minimum and maximum values.

\section{CPD}

$11,2585-2613,2015$

High resolution climate data from 5 GCMs of LGM

D. R. Schmatz et al.

\section{Title Page}

\section{Abstract}

Introduction

Conclusions

References

Tables

Figures

14

4

Back

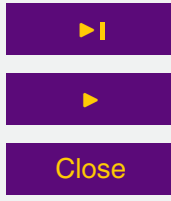

Full Screen / Esc

Printer-friendly Version

Interactive Discussion 

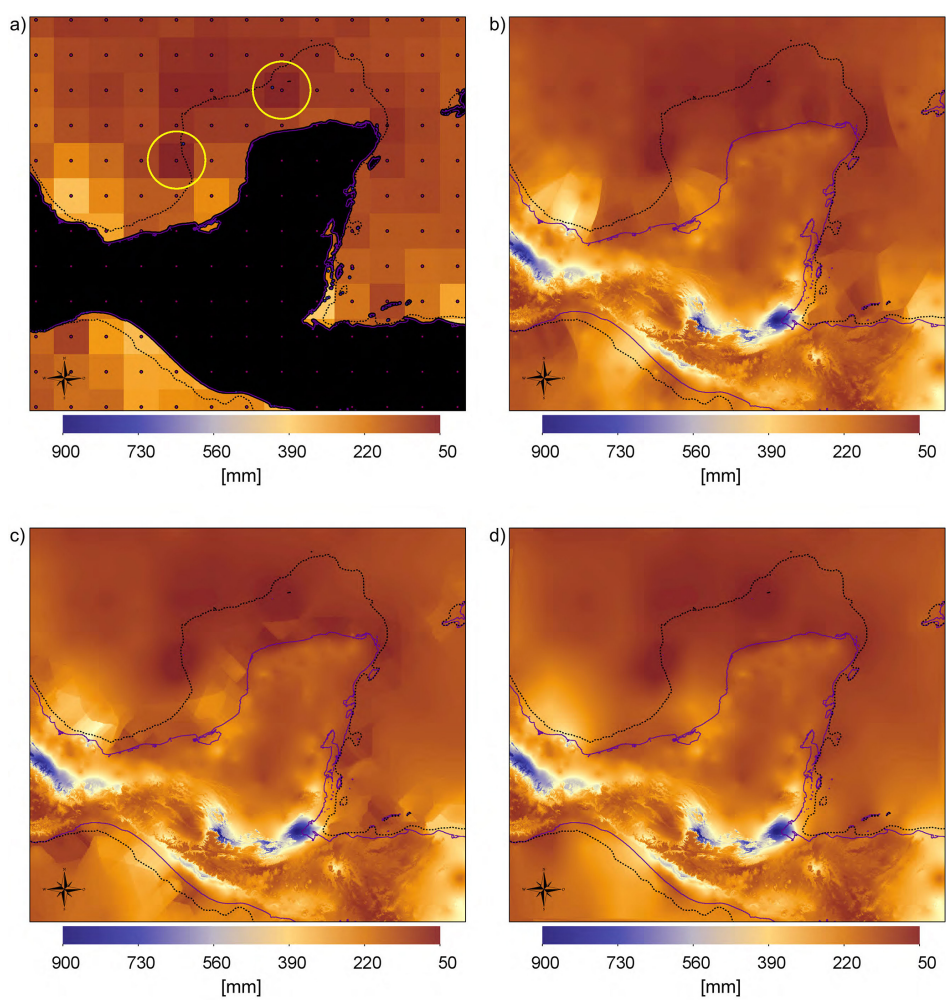

Figure A1. Interpolation tests for July precipitation in an area centered on the Yucatán Penninsula. Both the current coastline (solid) and the coast at the LGM (dotted) are shown. The maps show (a) unsmoothed data from application of "gdal_fillnodata" for marine areas combined with aggregated (1 deg) points originating from the 30 arc s WorldClim data for terrestrial areas. Terrestrial areas are visualized as black background area in the map. Interpolated data using (b) inverse distance weighting, (c) splines, and (d) the natural neighbor method. The effects of off-shore islands (circled dark red spots) and the interpolation artifacts caused by climate patterns along the current north coast of the Yucatán are evident.
CPD

$11,2585-2613,2015$

\section{High resolution climate data from 5 GCMs of LGM}

D. R. Schmatz et al.

\section{Title Page}

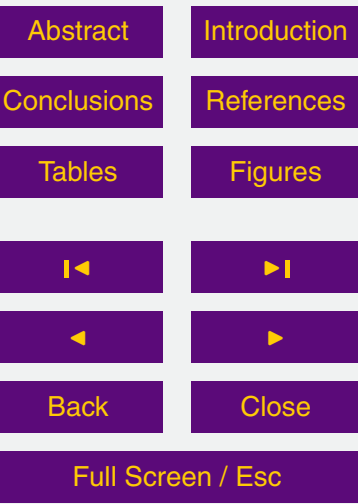

Printer-friendly Version

Interactive Discussion 